\title{
Melatonin regulation of transcription in the reversal of morphine tolerance: Microarray analysis of differential gene expression
}

\author{
YU-CHE CHENG ${ }^{1-3 *}$, RU-YIN TSAI ${ }^{4 *}$, YEN-TSENG SUNG $^{1}$, ING-JUNG CHEN ${ }^{5}$, \\ TZU-YI TU ${ }^{1}$, YA-YUAN MAO ${ }^{1}$ and CHIH-SHUNG WONG ${ }^{2,5,6}$ \\ ${ }^{1}$ Proteomics Laboratory, Department of Medical Research, Cathay General Hospital, Taipei 10630; ${ }^{2}$ School of Medicine, \\ Fu Jen Catholic University, New Taipei City 24205; ${ }^{3}$ Department of Biomedical Sciences and Engineering, \\ National Central University, Jhongli 32001; ${ }^{4}$ College of Nursing and Health Sciences, Da-Yeh University, \\ Changhua 51591; ${ }^{5}$ Department of Anesthesiology, Cathay General Hospital, Taipei 10630; \\ ${ }^{6}$ Institute of Medical Science, National Defense Medical Center, Taipei 11490, Taiwan, R.O.C.
}

Received June 20, 2018; Accepted December 11, 2018

DOI: $10.3892 /$ ijmm.2018.4030

\begin{abstract}
Tolerance and associated hyperalgesia induced by long-term morphine administration substantially restrict the clinical use of morphine in pain treatment. Melatonin, a neurohormone released by the pineal gland, has been demonstrated to attenuate anti-nociceptive morphine tolerance. The present study investigates differentially expressed genes in the process of morphine tolerance and altered gene expression subsequent to melatonin treatment in chronic morphine-infused ratspinal cords. Morphine tolerance was induced in male Wistar rats by intrathecal morphine infusion (the MO group). Melatonin (the MOMa group) was administered to overcome the effects derived by morphine. The mRNA collected from L5-S3 of the spinal cord was extracted and analysed by rat expression microarray. Principal component analysis and clustering analysis revealed that the overall gene profiles were different in morphine and melatonin treatments. Subsequent to Gene Ontology analysis, the biological processes of differentially expressed genes of MO and MOMa compared with the control group were constructed. Furthermore, a panel of genes exclusively expressed following melatonin treatment and another panel of genes with inverse expression between the MO and MOMa group were also established. Subsequent to PANTHER pathway analysis, a group of genes with inverse expression following melatonin administrated compared with morphine alone were identified. The expression levels of genes of interest were also confirmed using a reverse
\end{abstract}

Correspondence to: Dr Chih-Shung Wong, Department of Anesthesiology, Cathay General Hospital, 280 Renai Road, Taipei 10630, Taiwan, R.O.C.

E-mail:w82556@gmail.com

${ }^{*}$ Contributed equally

Key words: melatonin, morphine tolerance, gene expression transcription-quantitative polymerase chain reaction. The gene panel that was constructed suggests a potential signaling pathway in morphine tolerance development and is valuable for investigating the mechanism of morphine tolerance and the regulatory gene profiles of melatonin treatment. These results may contribute to the discovery of potential drug targets in morphine tolerance treatments in the future.

\section{Introduction}

Morphine is a powerful analgesic agent used for treating acute and chronic pain in surgical interventions or in hospice care (1). However, long-term administration of morphine induces tolerance and hyperalgesia. Furthermore, adverse effects, including addiction, dependence, constipation and respiratory depression limit its clinical usefulness $(2,3)$. The physiological responses of morphine tolerance include opioid receptor uncoupling, endocytosis/desensitization (4), increased binding of $\beta$-arrestin to opioid receptors, glutamatergic receptor activation and neuroinflammation (5). Melatonin is a neurohormone derived from serotonin and is released from the pineal gland (6). It is used for sleep modulation and relieves the stress caused by sleep disturbance (1). It has previously been revealed that melatonin treatment partially reverses morphine tolerance by inhibiting microglia activation though a heat shock protein 27 (HSP27)-associated pathway (7). Furthermore, melatonin co-treatment was revealed to prevent morphine-induced hyperalgesia and tolerance in rats, potentially by inhibiting protein kinase C-associated pathways $(8,9)$. A report also demonstrated that decreased mitochondrial DNA copy numbers in the hippocampus during opiate addiction were mediated by autophagy and may be reversed by melatonin (10). Additionally, melatonin was revealed to enhance the reward behaviour of morphine via the nitric oxidergic pathway (11). Raghavendra and Kulkarni initially reported that the systemic administration of melatonin reversed morphine-induced tolerance in mice (12). Song et al (8) identified that daily intraperitoneal melatonin treatment reduced morphine tolerance in rats via the regulation of the $\mathrm{N}$-methyl-D-aspartate receptor 
subunit 1. Furthermore, Garmabi et al (13) observed a reduction of melatonin levels in rats under constant light exposure; those animals also presented a high morphine consumption and severe morphine withdrawal syndrome. Fan et al (14) further reported a substantial decrease of serum melatonin and melatonin receptor 1 mRNA subsequent to chronic morphine infusion in rats. Previously, not only was it revealed that melatonin treatment partially reversed morphine tolerance by inhibiting microglia activation though a HSP27-associated pathway (7), but preliminary examinations additionally revealed that chronic morphine treatment resulted in transcriptomics changes. All studies noted that melatonin participates in the morphine tolerance pathway. Although melatonin was demonstrated to diminish morphine tolerance, the transcriptomic changes derived from melatonin treatment in opiate tolerance remain undetermined. To search whole genome expression profiles disturbed by long-term morphine administration and clarify the gene alterations caused by melatonin, an expression array was used in the present study to examine the effects of melatonin treatment on morphine-induced tolerance in rats. The results may provide insight on and contribute to deciphering the detailed mechanisms of morphine tolerance.

\section{Materials and methods}

Construction of intrathecal catheters. The intrathecal (i.t.) catheters were constructed by inserting a $3.5 \mathrm{~cm}$ Silastic tube (Corning Incorporated, Corning, NY, USA) into an $8 \mathrm{~cm}$ polyethylene tube (0.008 inch internal diameter, 0.014 inch outer diameter; Spectranetics, Colorado Springs, CO, USA) and sealing the joint with epoxy resin and silicon rubber as previously described (15).

Animal preparation and intrathecal drug delivery. The use of rats in the present study adhered to the Guiding Principles in the Care and Use of Animals of the American Physiology Society (16) and was ethically approved by the National Defense Medical Center Animal Care and Use Committee (Taipei, Taiwan). A total of 27 Male Wistar rats (350-400 g), each rat (with 12 weeks of age) was housed individually at a room temperature at $25^{\circ} \mathrm{C}$, at $1 \mathrm{~atm}$, with water and food freely as wish. The rats were anaesthetized with phenobarbital $(65 \mathrm{mg} / \mathrm{kg}$, intraperitoneally) and two i.t. catheters were implanted. The catheters were inserted via the atlantooccipital membrane down to spinal cord segments L5, L6 and S1-S3, which are associated with the tail-flick reflex (17). One catheter was connected to a mini-osmotic pump (Alzet, Cupertino, CA, USA) for an infusion of saline or morphine $(15 \mu \mathrm{g} / \mathrm{h})$ for 7 days at a rate of $1 \mu \mathrm{l} / \mathrm{h}$. Subsequent to catheterization (day 0 ), the rats were returned to their home cages and maintained in a $12 \mathrm{~h}$ light/dark cycle with ad libitum access to food and water. Rats with neurological deficits were excluded. On day 7, by which time a morphine tolerance had developed, the catheter used for saline or morphine infusion was cut and blocked with a metal metal plug to prevent CSF leakage. The rats were injected i.t. via the second catheter with $5 \mu \mathrm{l}$ either with vehicle (10\% ethanol) or melatonin (50 $\mu \mathrm{g}$ in $10 \%$ ethanol), then, 30 min later, a single dose of morphine (15 $\mu \mathrm{g}$ in $5 \mu \mathrm{l}$ saline, i.t.) was injected and the antinociceptive
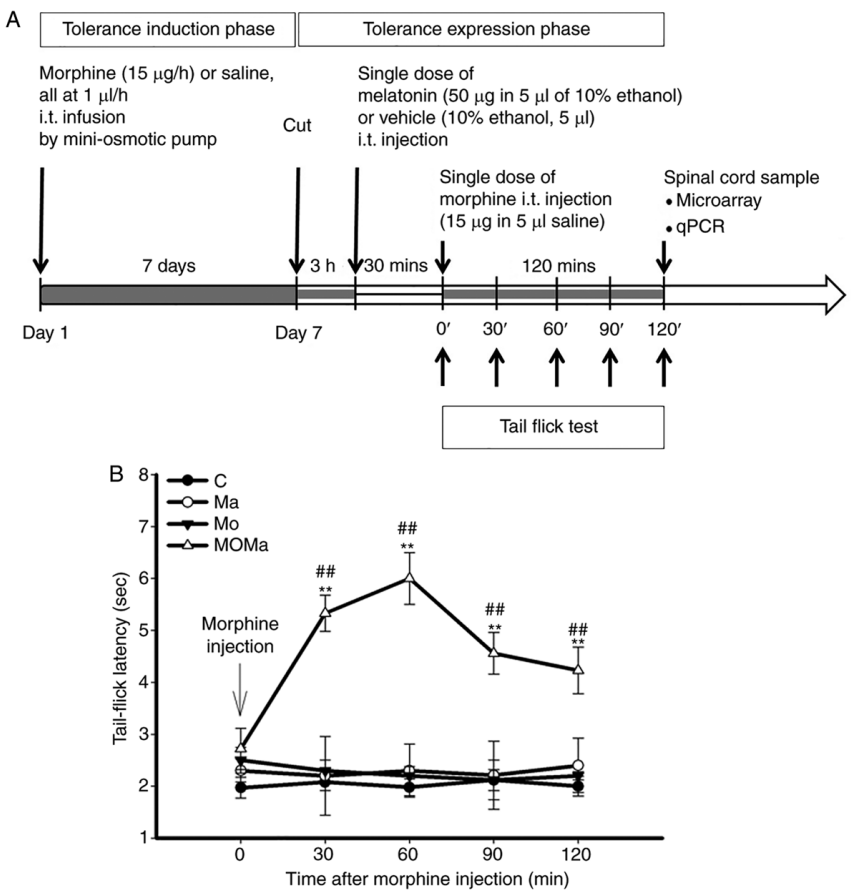

Figure 1. Experimental procedure and effect of melatonin on the antinocieptive effect in morphine-tolerant rats. (A) Experimental procedure for drug administration. Male Wistar rats were implanted with two i.t. catheters, one of which was connected to a mini-osmotic pump for the infusion of morphine or saline for 7 days. On day 7, subsequent to morphine tolerance development, the catheter was cut, and $3 \mathrm{~h}$ later the rats were injected intrathecally with either vehicle or melatonin via the second catheter. A total of $30 \mathrm{~min}$ later, a single dose of morphine $(15 \mu \mathrm{g})$ was injected intrathecally and its antinociceptive effect measured. (B) Melatonin reverses the antinociceptive effect of morphine in morphine-tolerant rats. Antinociception of morphine was assessed on day 7 following intrathecal infusion of saline or morphine. At $3 \mathrm{~h}$ subsequent to the discontinuation of infusion, the rats were injected intrathecally with $10 \%$ ethanol (as vehicle) or $50 \mu \mathrm{g}$ melatonin. After $30 \mathrm{~min}$, the rats underwent a $15 \mu \mathrm{g}$ morphine administration, then tail-flick latency was measured every $30 \mathrm{~min}$ for $120 \mathrm{~min}$. All data are presented as the mean \pm standard error of the mean for at least 5 rats. ${ }^{* *} \mathrm{P}<0.01 \mathrm{vs}$. the Ma group; ${ }^{\#} \mathrm{P}<0.01$ vs. the MO group. $\mathrm{C}$, control (saline infusion/vehicle injection/saline challenge); MO, morphine (morphine infusion/vehicle injection/morphine challenge); Ma, melatonin (morphine infusion/melatonin injection/saline challenge); MOMa, (morphine infusion/melatonin injection/morphine challenge); i.t., intrathecal; qPCR, quantitative polymerase chain reaction.

effect measured. The protocol is presented in Fig. 1A. There were four experimental groups used in the present study, as follows: Controls, melatonin-treated, morphine-treated and those treated with melatonin and morphine combined. For the control group, the animals were infused with saline for 7 days and infused with vehicle injection for $30 \mathrm{~min}$, and subsequently injected with saline. For the morphine group, the animals were infused with morphine for 7 days, injected with vehicle injection for $30 \mathrm{~min}$ and subsequently injected with morphine. For the melatonin group, the animals were infused with morphine for 7 days and injected with melatonin for $30 \mathrm{~min}$, and subsequently injected with saline. For the melatonin and morphine group, the animals were infused with morphine for 7 days, injected with melatonin for 30 min and subsequently injected with morphine.

The dose of morphine selected was based on a previous study (18). For i.t. injection, melatonin was dissolved in ethanol (50 $\mu \mathrm{g} / 5 \mu \mathrm{l}$ in $10 \%$ ethanol maximum). All drugs were 
purchased from Sigma-Aldrich (Merck KGaA, Darmstadt, Germany) and were delivered i.t., followed by the flushing of the catheter with $5 \mu 1$ saline. Preliminary results revealed no abnormal motor function subsequent to i.t. injection of the test drugs (data not shown).

Antinociception test. Tail-flick latency was measured using the hot water immersion test $\left(52 \pm 0.5^{\circ} \mathrm{C}\right)$. Baseline latency was $\sim 2 \pm 0.38 \mathrm{sec}$, and a cutoff time of $10 \mathrm{sec}$ was used. Rats were placed in plastic restrainers for drug injection and antinociception testing.

Spinal cord sample collection from rats with different treatments. Spinal cord sample collection was performed as previously described (7), and morphine tolerance in rats was confirmed by the time-course of tail-flick latency over a 7-day period. Prior to day 4, the rats with morphine infusions demonstrated a reduction of tail-flick latency compared with the saline-infused group, which exhibited no changes in latency during the period. Substantial morphine tolerance was developed on day 7 as determined by a significant reduction of the antinociceptive effect of morphine compared with day one, with a reduction of the tail-flick latency of $\sim 60 \%$. And then, rats were i.t. injected with either $10 \%$ ethanol (as a vehicle) or melatonin via the externalized i.t. catheter. A total of $30 \mathrm{~min}$ later, a single dose of morphine $(15 \mu \mathrm{g})$ was injected i.t. to confirm morphine tolerance. In contrast, melatonin pretreatment attenuated morphine tolerance, melatonin pretreatment was done by administering melatonin on day 7 , at $30 \mathrm{~min}$ prior to morphine intrathecal injection. The lumbar enlargement segment was removed from 4 rat spinal cords from each group for differential gene expression analysis.

Spinal cord sample preparation. Following drug treatment, the rats were sacrificed by exsanguination under anaesthesia with isoflurane (Abbott Pharmaceutical Co. Ltd., Lake Bluff, IL, USA) and a laminectomy was performed at the lower edge of the 12th thoracic vertebra. Subsequently, the lumber enlargement (L5-S3) of the spinal cord was immediately collected for subsequent analysis.

Rat expression microarray. Following the tail-flick test, the rats were sacrificed, and lumber enlargement (L5-S3) of the spinal cord was immediately collected. There were 4 samples tested in each group. Total mRNAs were extracted using TRIzol reagent (Invitrogen; Thermo Fisher Scientific, Inc., Waltham, MA, USA). RNA concentration and purity were assessed using an Agilent 2100 Bioanalyzer (Agilent Technologies, Inc., Santa Clara, CA, USA) with a criteria of OD260/OD280 (>1.8) and OD260/OD230 (>1.6). Next, the RNAs were labelled with Cy5 dye by an indirect NHS ester labelling kit (GE Healthcare, Chicago, IL, USA) according to the manufacturer's protocol. The labelled RNAs were hybridized with a Rat OneArray ${ }^{\circledR}$ microarray (Phalanx Biotech Group, Hsinchu, Taiwan), which contains 24,358 rat genome probes and 980 experimental control probes. All the probes correspond to annotated genes in RefSeq and Ensembl databases. The hybridization procedure was performed at $50^{\circ} \mathrm{C}$ in a Phalanx Hybridization System
(Phalanx Biotech Group). A total of $16 \mathrm{~h}$ after hybridization, non-specific binding targets were washed away using three sequential washing steps by $2 \mathrm{X}$ saline-sodium citrate buffer (SSC) contained $0.2 \%$ SDS solution for $5 \mathrm{~min}$ at $42^{\circ} \mathrm{C}$. Then, the slide was spun dry with a centrifuge for $1 \mathrm{~min}$ at room temperature. The images of the microarray were scanned using an Agilent G2505C scanner (Agilent Technologies, Inc.). The Cy5 fluorescence intensities of each spot were analysed by GenePix 4.1 software (Molecular Devices, LLC, Sunnyvale, CA, USA).

Microarray analysis. Microarray spot analysis was resolved by the Rosetta Resolver System ${ }^{\circledR}$ (Rosetta Biosoftware, Seattle, WA, USA). Control probes data were calculated, and the reproducibility of each microarray slide was assessed using Pearson's correlation coefficient calculations with a criterion of R-value $>0.975$. Normalized spot intensities were transformed to gene expression $\log _{2}$ ratios in each group. For further analysis, the spots with a $\log _{2}$ ratio $\geq 1$ or a $\log _{2}$ ratio $\leq-1$ or undetectable $\log _{2}$ ratios but with differences in intensity between the two samples of $>1,000$ and a $P<0.05$ were selected according to the method of Pirooznia et al (19). Principal Component Analysis (PCA) was performed to evaluate any differences among biological replicates and their treatment conditions using FDA released ArrayTrack ${ }^{\mathrm{TM}}$ HCA-PCA Standalone Package (20). PCA uses an orthogonal transformation to convert a set of observations of possibly correlated variables into a set of values of uncorrelated variables called principal components. For advanced data analysis, intensity data were pooled and calculated to identify differentially expressed genes based on the threshold of fold-change and P-value. The correlation of expression profiles between samples and treatment conditions was demonstrated by unsupervised hierarchical clustering analysis. Average linkage clustering was performed to visualize the correlations among the replicates and varying sample conditions using and open source software, Java Treeview (21). Up and downregulated genes are represented in red and green colors, respectively.

Gene ontology $(G O)$ enrichment analysis. The gene IDs of interest were uploaded to the Gene ontology Enrichment analysis website (22). The database and analysis services were funded by the National Human Genome Research Institute in the U.S. And right now the website were maintained and updated by the Gene Ontology Consortium (GOC). The names of the genes with interested were paste to the query column in the website and set the GO aspect as molecular function for the analysis. The database search was confined to Rattus norvegicus database.

Gene pathway mapping by PANTHER. The gene IDs of interest were uploaded to the PANTHER Classification System website (http://pantherdb.org). PANTHER is a comprehensive, curated database of protein families, trees, subfamilies, functions and ontology (23). The search parameter was set to 'molecular function', and the database search was confined to only the Rattus norvegicus database. The keywords used were the gene names of interest and the access date were December 12 and 19, 2017. 
Table I. Primers used for reverse transcription-quantitative polymerase chain reaction analysis.

\begin{tabular}{|c|c|c|c|}
\hline Target gene & Gene ID & Position & Sequence \\
\hline G protein subunit $\beta 1$ (Gnb1) & NM_030987.2 & $\begin{array}{l}F: 262-281 \\
R: 317-337\end{array}$ & $\begin{array}{l}\text { 5'-tccagtgggaagaatccaaa-3' } \\
\text { 5'-ccagtgcatggcataaatctt-3' }\end{array}$ \\
\hline Cholecystokinin B receptor (Cckbr) & NM_013165.2 & $\begin{array}{l}\text { F:1799-1819 } \\
\text { R:1842-1861 }\end{array}$ & $\begin{array}{l}5^{\prime} \text {-cccgtttgacttcattattgc-3' } \\
5^{\prime} \text {-tgaaaggcgtgtggttgata-3' }\end{array}$ \\
\hline $\begin{array}{l}\text { 5-hydroxytryptamine } \\
\text { receptor } 1 \mathrm{~A}(\mathrm{Htr} 1 \mathrm{a})\end{array}$ & NM_012585.1 & $\begin{array}{l}\text { F: } 1054-1072 \\
\text { R:1110-1128 }\end{array}$ & $\begin{array}{l}\text { 5'-ggcaccttcatcctctgct-3' } \\
5^{\prime} \text {-gtggcagctgctttcacag-3' }\end{array}$ \\
\hline RAS protein activator like 1 (Rasal1) & NM_001108335.1 & $\begin{array}{l}\text { F:408-429 } \\
\text { R:451-470 }\end{array}$ & $\begin{array}{l}\text { 5'-ggagtacactgttcaccttcca-3' } \\
\text { 5'-tcctcatccagcacgtagaa-3' }\end{array}$ \\
\hline $\begin{array}{l}\text { General transcription } \\
\text { factor } 2 \mathrm{~A} \text { subunit } 1 \text { like (Gtf2a1l) }\end{array}$ & NM_001012136.1 & $\begin{array}{l}\text { F: } 1222-1242 \\
\text { R:1267-1289 }\end{array}$ & $\begin{array}{l}\text { 5'-gaggatcccctaaattctgga-3' } \\
5^{\prime} \text {-ttatctgtgtcaaacaggtctgg-3' }\end{array}$ \\
\hline Period circadian clock 1 (Per1) & NM_001034125.1 & $\begin{array}{l}\text { F:1986-2008 } \\
\text { R:2043-2062 }\end{array}$ & $\begin{array}{l}\text { 5'-tcctaacacaaccaagcgtaaat-3 } \\
5^{\prime} \text {-ccctctgcttgtcatcatca-3' }\end{array}$ \\
\hline $\begin{array}{l}\text { Methionine adenosyltransferase } 2 \mathrm{~A} \\
\text { (Mat2a) }\end{array}$ & NM_134351.1 & $\begin{array}{l}\mathrm{F}: 149-168 \\
\mathrm{R}: 204-222\end{array}$ & $\begin{array}{l}\text { 5'-tgtaggggaaggtcatccag-3' } \\
5^{\prime} \text {-cctgctgaaggtgtgcatc-3' }\end{array}$ \\
\hline Collagen type $\mathrm{V} \alpha 3$ chain (Col5a3) & NM_021760.1 & $\begin{array}{l}F: 634-652 \\
R: 673-693\end{array}$ & $\begin{array}{l}\text { 5'-cggggaggagtcttttgag-3' } \\
5^{\prime} \text {-gcctgagggtctggaattaac-3' }\end{array}$ \\
\hline $\begin{array}{l}\text { Inositol 1,4,5-trisphosphate } \\
\text { receptor, type } 3 \text { (Itpr3) }\end{array}$ & NM_013138.1 & $\begin{array}{l}F: 8362-8381 \\
R: 8403-8422\end{array}$ & $\begin{array}{l}\text { 5'-taggggatgcaagttctcca-3' } \\
\text { 5'-ccactgagaaatgccagtca-3' }\end{array}$ \\
\hline Diacylglycerol kinase $\zeta($ Dgkz) & NM_031143.1 & $\begin{array}{l}F: 330-347 \\
R: 410-429\end{array}$ & $\begin{array}{l}\text { 5'-ctttgggcacaggaaagc-3' } \\
5^{\prime} \text {-gatctgccgctcagattcac-3' }\end{array}$ \\
\hline $\begin{array}{l}\text { LIM zinc finger domain containing } 2 \\
\text { (Lims2) }\end{array}$ & NM_001012163.1 & $\begin{array}{l}\text { F:966-985 } \\
\text { R:1032-1051 }\end{array}$ & $\begin{array}{l}\text { 5'-tcatgtgattgagggtgacg-3' } \\
5^{\prime} \text { 'ccaccaggagaacagactgg-3' }\end{array}$ \\
\hline
\end{tabular}

F, forward; R, reverse.

RNA extraction and reverse transcription-quantitative polymerase chain reaction $(R T-q P C R)$. Tissues were collected as described above. RNA was extracted within $1 \mathrm{~h}$ at room temperature using TRIzol reagent following manufacturer's protocol (Invitrogen; Thermo Fisher Scientific, Inc.). mRNA were reverse transcribed to cDNA using the SuperScript III First-Strand Synthesis System (Invitrogen; Thermo Fisher Scientific, Inc.). cDNA were amplified and subjected to optical analysis to verify the integrity of extracted RNA. The expression of target genes were quantified for all experimental groups using LightCycler system (Roche Diagnostics, Basel, Switzerland). RT-qPCR analysis thermocycling conditions were: $95^{\circ} \mathrm{C}$ for $10 \mathrm{~min}$ and then the cycling conditions were set as $95^{\circ} \mathrm{C}$ for $10 \mathrm{sec}, 60^{\circ} \mathrm{C}$ for $20 \mathrm{sec}, 72^{\circ} \mathrm{C}$ for $40 \mathrm{sec}$ for 50 cycles. The method of quantification for RT-qPCR products were followed Livak and Schmittgen et al (24) The relative abundance of transcripts were normalized to the constitutive expression of GAPDH. The primers of each genes used in RT-qPCR were listed in Table I.

Data and statistical analyses. All data are presented as the mean \pm standard error of the mean. Statistical analysis was performed using SigmaStat 3.0 software (SYSTAT Software Inc., San Jose, CA, USA). Tail-flick latencies were analyzed using two-way (time and treatment) analysis of variance (ANOVA), followed by one-way ANOVA with a post hoc Student-Newman-Keuls test. The RT-qPCR results were analyzed using a Student's t-test. $\mathrm{P}<0.05$ was considered to indicate a statistically significant difference.

\section{Results}

Experimental design and procedure. The experimental procedure for drug administration was depicted in Fig. 1. Male Wistar rats were implanted with two i.t. catheters and connected to a mini-osmotic pump for morphine or saline infusion for 7 days for morphine tolerance induction. On day 7 , subsequent to the development of tolerance, the catheter was cut, and $3 \mathrm{~h}$ later, the rats received an i.t. injection of either vehicle or melatonin via the other catheter. A total of $30 \mathrm{~min}$ later, at the tolerance expression phase, a single dose of morphine $(15 \mu \mathrm{g})$ was injected i.t., and the antinociceptive effect was measured. Tail flick tests were performed in every experimental group and the results were presented in Fig. 1B. There was a significant reduction of morphine tolerance subsequent to melatonin addition compared with the control group $(\mathrm{P}<0.01)$. Following a tail-flick test, the rats were sacrificed, and the $\mathrm{L} 5$ to $\mathrm{S} 3$ region of the spinal cords were collected for further analysis.

Differential gene expression among morphine tolerance, melatonin treatment and morphine tolerance combined with melatonin treatment groups. To determine the alterations in gene expression caused by morphine and reversed by melatonin treatment in rat spinal cords, rat global gene expression profiles of four independent RNA samples from each group 
Table II. Number of differentially expressed genes.

\begin{tabular}{lcc}
\hline Group comparison & Upregulated & Downregulated \\
\hline $\mathrm{MO} / \mathrm{C}$ & 162 & 16 \\
$\mathrm{MOMa} / \mathrm{C}$ & 290 & 15 \\
$\mathrm{Ma} / \mathrm{C}$ & 476 & 71 \\
\hline
\end{tabular}

Standard selection criteria to identify differentially expressed genes are as follows: i) $\log _{2}$ IFold changel $\geq 1$ and $\mathrm{P}<0.05$; ii) $\log _{2}$ ratios $=$ 'NA' and the differences of intensity between the two samples $\geq 1000$. Detail gene lists were be provided by request. C, control (saline infusion/vehicle injection/saline challenge); Mo, morphine (morphine infusion/vehicle injection/morphine challenge); Ma, melatonin (morphine infusion/melatonin injection/saline challenge); MOMa, (morphine infusion/melatonin injection/morphine challenge).

\section{Upregulated}

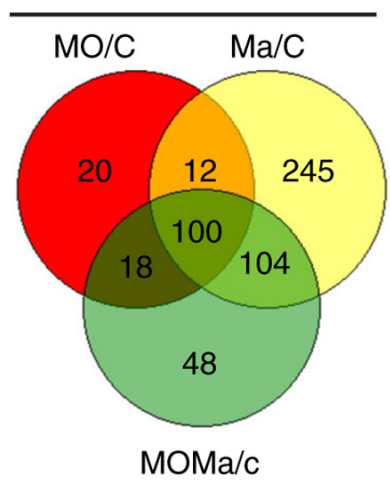

Figure 2. Venn diagram analysis of the genes that were upregulated (left) or downregulated (right) by morphine tolerance and/or melatonin treatment compared with the control group. In each pair test, the upregulated genes were identified as follows: $\log _{2} \mid$ Fold changel $\geq 1$ and $P<0.05$ In the diagram, red circles represent genes putatively affected by long-term morphine application, yellow circles represent genes influenced by melatonin treatment and green circles represent genes for which melatonin-induced expression changes were putatively affected by morphine. All genes considered were differentially expressed compared with the untreated group. C, control (saline infusion/vehicle injection/saline challenge); $\mathrm{MO}$, morphine (morphine infusion/vehicle injection/morphine challenge); Ma, melatonin (morphine infusion/melatonin injection/saline challenge); MOMa, (morphine infusion/melatonin injection/morphine challenge).

were selected for microarray analysis. PCA and clustering analysis revealed that the overall gene profiles derived from microarray analysis were separated based on morphine or melatonin treatment. The result revealed that 162 genes were upregulated and 16 genes were downregulated in the morphine-tolerant group (MO group, $n=7$ ) compared with the control group ( $\mathrm{C}$ group, $\mathrm{n}=5$ ); 476 genes were upregulated and 71 genes were downregulated in the melatonin treatment group (Ma group, $n=5$ ) compared with the control group (C group), and 290 genes were upregulated and 15 genes were downregulated in the morphine with acute melatonin treatment group (MOMa group, $n=10$ ) compared with the control group (Table II). All genes selected using the criteria of $\log _{2} \mid$ Fold changel $\geq 1$ and $\mathrm{P}<0.05$ or undetectable $\log _{2}$ ratios but with differences in intensity between the two samples of
$>1,000$. Statistical significance was used to avoid confounding due to variation amongst the animals and addressed additional evidence that the transcriptional profiles of morphine tolerance and melatonin treatment in vivo are different. The present study compared the number of upregulated genes between the MO and MOMa groups; it was identified that the number of upregulated genes in the MOMa group was greater compared with the number in the MO group, which indicated that melatonin restored the antinociceptive effect of morphine, which was accomplished with multiple gene expression alterations.

Gene ontology (GO) analysis of the altered genes from the MO or MOMa group. The differentially expressed genes were then subjected to GO analysis based on molecular function (Table III). Numerous GO terms were identical between the two groups; however, opsonin binding, actin binding, calcium ion binding, sugar binding, oxidase activity, deaminase activity, protein complex binding and oxidoreductase activity were not identified in the MO group. On the other hand, GTPase activity, phospholipase inhibitor activity, cytokine activity, GTP binding, guanyl-nucleotide and ribonucleotide binding, immunoglobulin $(\mathrm{Ig}) \mathrm{G}$ receptor activity, IgE binding and protein dimerization activity were not identified in the MOMa group, implying the potential regulatory mechanism of melatonin treatment. From the GO terms identified between the MO and MOMa groups, it was revealed that a number of notable pathways were altered. It has been previously reported that the morphine tolerance process involves inflammation (25). Immune-associated processes, including cytokine activity, IgG receptor activity and IgE binding, were missing following melatonin treatment, which indicates that melatonin treatment may participate in the downregulation of these cellular process. On the other hand, the gene expression for actin binding was present following melatonin treatment; this result implies that cytoskeleton reconstitution may be activated. Additionally, genes involving calcium ion binding, sugar binding, NADPH oxidase activity, deaminase activity and protein complex binding pathways appeared subsequent to melatonin treatment, indicating the requirement for the metabolic activity that emerged following melatonin treatment. The gene expression data for IgG receptor expression and actin binding were selected and provided by request.

Venn diagram and genes exclusively expressed in the MOMa group. In order to clarify the differential gene expression panels among the three groups, Venn diagram analysis was performed, and the results depicted the overlap of differentially expressed genes between the MO, Ma and MOMa groups (Fig. 2). In total, 48 genes were upregulated and 8 were genes downregulated exclusively in the MOMa group. These genes were the candidates that participated in the reversal of morphine tolerance. It was also identified that 20 genes were upregulated and 13 genes were downregulated exclusively in the MO group; these genes were not altered by melatonin treatment, so these genes were not involved in the melatonin reversal effect in morphine tolerance. All the genes in Venn diagram analysis are listed in Table IV-A and -B. Genes expressed exclusively in the MOMa group are notable as they may be the targets for the reversal of morphine tolerance associated with melatonin in future studies. From Table IV-B, the myocilin gene demonstrated the greatest 
Table III. Identified gene ontology terms of the MO and MOMa groups compared with the C group.

\begin{tabular}{|c|c|c|c|c|c|c|}
\hline \multirow[b]{2}{*}{ Geneset name } & \multicolumn{3}{|c|}{$\mathrm{MO} / \mathrm{C}$} & \multicolumn{3}{|c|}{$\mathrm{MOMa} / \mathrm{C}$} \\
\hline & $\begin{array}{l}\text { No. of } \\
\text { genes in geneset }\end{array}$ & $\begin{array}{l}\text { No. of genes } \\
\text { in overlap }\end{array}$ & P-value & $\begin{array}{l}\text { No. of genes } \\
\text { in geneset }\end{array}$ & $\begin{array}{l}\text { No. of genes } \\
\text { in overlap }\end{array}$ & P-value \\
\hline GO:0001846-opsonin binding & & N.I. & & 7 & 3 & $<0.01$ \\
\hline GO:0001871-pattern binding & 116 & 7 & $<0.01$ & 116 & 13 & $<0.01$ \\
\hline GO:0001872-zymosan binding & 3 & 2 & 0.02 & 3 & 2 & 0.04 \\
\hline GO:0003924-GTPase activity & 98 & 4 & 0.05 & & N.I. & \\
\hline GO:0003779-actin binding & & N.I. & & 233 & 10 & 0.01 \\
\hline GO:0004857-enzyme inhibitor activity & 238 & 10 & $<0.01$ & 238 & 11 & $<0.01$ \\
\hline GO:0004859-phospholipase inhibitor activity & 6 & 2 & 0.05 & & N.I. & \\
\hline GO:0004866-endopeptidase inhibitor activity & 148 & 6 & 0.01 & 148 & 7 & 0.02 \\
\hline GO:0005125-cytokine activity & 110 & 5 & 0.01 & & N.I. & \\
\hline GO:0005506-iron ion binding & 289 & 7 & 0.03 & 289 & 10 & 0.03 \\
\hline GO:0005525-GTP binding & 312 & 8 & 0.02 & & N.I. & \\
\hline GO:0005509-calcium ion binding & & N.I. & & 672 & 20 & 0.01 \\
\hline GO:0005529-sugar binding & & N.I. & & 215 & 9 & 0.02 \\
\hline GO:0005539-glycosaminoglycan binding & 102 & 5 & 0.01 & 102 & 11 & $<0.01$ \\
\hline GO:0008009-chemokine activity & 32 & 5 & $<0.01$ & 32 & 4 & 0.01 \\
\hline GO:0008201-heparin binding & 72 & 4 & 0.02 & 72 & 8 & $<0.01$ \\
\hline $\begin{array}{l}\text { GO:0016175-superoxide-generating } \\
\text { NADPH oxidase activity }\end{array}$ & & N.I. & & 7 & 3 & $<0.01$ \\
\hline $\begin{array}{l}\text { GO:0016814 hydrolase activity, acting on } \\
\text { carbon-nitrogen (but not peptide) bonds, } \\
\text { in cyclic amidines }\end{array}$ & 22 & 3 & 0.01 & 22 & 4 & $<0.01$ \\
\hline GO:0019239-deaminase activity & & N.I. & & 21 & 3 & 0.04 \\
\hline GO:0019001-guanyl nucleotide binding & 326 & 8 & 0.02 & & N.I. & \\
\hline $\begin{array}{l}\text { GO:0019763-immunoglobulin } \\
\text { receptor activity }\end{array}$ & 7 & 3 & $<0.01$ & 7 & 3 & $<0.01$ \\
\hline GO:0019770-IgG receptor activity & 4 & 2 & 0.03 & & N.I. & \\
\hline $\begin{array}{l}\text { GO:0019834-phospholipase A2 } \\
\text { inhibitor activity }\end{array}$ & 3 & 2 & 0.02 & 3 & 2 & 0.04 \\
\hline GO:0019863-IgE binding & 4 & 2 & 0.03 & & N.I. & \\
\hline GO:0019864-IgG binding & 6 & 4 & $<0.01$ & 6 & 4 & $<0.01$ \\
\hline GO:0019865-immunoglobulin binding & 12 & 5 & $<0.01$ & 12 & 5 & $<0.01$ \\
\hline GO:0019955-cytokine binding & 87 & 4 & 0.04 & 87 & 7 & $<0.01$ \\
\hline GO:0020037-heme binding & 148 & 5 & 0.04 & 148 & 7 & 0.02 \\
\hline GO:0030246-carbohydrate binding & 337 & 10 & $<0.01$ & 337 & 20 & $<0.01$ \\
\hline GO:0030247-polysaccharide binding & 116 & 7 & $<0.01$ & 116 & 13 & $<0.01$ \\
\hline GO:0030414-peptidase inhibitor activity & 159 & 7 & $<0.01$ & 159 & 8 & 0.01 \\
\hline GO:0032403-protein complex binding & & N.I. & & 222 & 12 & $<0.01$ \\
\hline GO:0032561-guanyl ribonucleotide binding & 326 & 8 & 0.02 & & N.I. & \\
\hline GO:0042379-chemokine receptor binding & 33 & 5 & $<0.01$ & 33 & 4 & 0.01 \\
\hline GO:0042802-identical protein binding & 588 & 11 & 0.02 & 588 & 18 & 0.01 \\
\hline GO:0042803-protein homodimerization activity & 318 & 8 & 0.02 & 318 & 15 & $<0.01$ \\
\hline GO:0046906-tetrapyrrole binding & 154 & 5 & 0.04 & 154 & 7 & 0.03 \\
\hline GO:0046983-protein dimerization activity & 528 & 10 & 0.03 & 528 & 20 & $<0.01$ \\
\hline GO:0048020-CCR chemokine receptor binding & 3 & 2 & 0.02 & & N.I. & \\
\hline $\begin{array}{l}\text { GO:0050664-oxidoreductase activity, acting on } \\
\text { NADH or NADPH, with oxygen as acceptor }\end{array}$ & & N.I. & & 11 & 3 & 0.01 \\
\hline
\end{tabular}

N.I., not identified; Ig, immunoglobulin; GO, Gene Ontology; C, control (saline infusion/vehicle injection/saline challenge); Mo, morphine (morphine infusion/vehicle injection/morphine challenge); Ma, melatonin (morphine infusion/melatonin injection/saline challenge); MOMa, (morphine infusion/melatonin injection/morphine challenge). 
Table IV. Top 20 exclusively upregulated and downregulated genes in each group.

A, Exclusively expressed genes in MO group

\begin{tabular}{|c|c|c|c|}
\hline Gene symbol & Description & Gene ID & Fold-change \\
\hline Ddx60 & $\begin{array}{l}\text { DEAD (Asp-Glu-Ala-Asp) box polypeptide } 60 \text {, } \\
\text { probable ATP-dependent RNA helicase DDX60-like }\end{array}$ & 100360801 & $1.61 \mathrm{Up}$ \\
\hline Lgals3bp & $\begin{array}{l}\text { Lectin, galactoside-binding, soluble, } \\
3 \text { binding protein }\end{array}$ & 245955 & $1.54 \mathrm{Up}$ \\
\hline Oas1a & 2'-5' oligoadenylate synthetase $1 \mathrm{~A}$ & 192281 & $1.47 \mathrm{Up}$ \\
\hline Isg15 & ISG15 ubiquitin-like modifier & 298693 & $1.46 \mathrm{Up}$ \\
\hline Slamf9 & SLAM family member 9 & 289235 & $1.29 \mathrm{Up}$ \\
\hline Usp18 & Ubiquitin specific peptidase 18 & 312688 & $1.28 \mathrm{Up}$ \\
\hline Smim5 & Small integral membrane protein 5 & 689926 & $1.26 \mathrm{Up}$ \\
\hline Casp4 & Caspase 4, apoptosis-related cysteine peptidase & 114555 & $1.2 \mathrm{Up}$ \\
\hline $\mathrm{Cd} 33$ & CD33 molecule & 690492 & $1.2 \mathrm{Up}$ \\
\hline Pik3ap1 & Phosphoinositide-3-kinase adaptor protein 1 & 294048 & $1.14 \mathrm{Up}$ \\
\hline $\mathrm{Ccl} 7$ & Chemokine (C-C motif) ligand 7 & 287561 & $1.13 \mathrm{Up}$ \\
\hline Apol9a & Apolipoprotein L 9a & 503164 & $1.11 \mathrm{Up}$ \\
\hline Dpt & Dermatopontin & 289178 & $1.09 \mathrm{Up}$ \\
\hline Cryaa & Crystallin, $\alpha \mathrm{A}$ & 24273 & $1.06 \mathrm{Up}$ \\
\hline Irgm & Immunity-related GTPase family, M & 303090 & $1.05 \mathrm{Up}$ \\
\hline Irf7 & Interferon regulatory factor 7 & 293624 & $1.04 \mathrm{Up}$ \\
\hline Gpr160 & G protein-coupled receptor 160 & 499588 & $1.03 \mathrm{Up}$ \\
\hline Uba7 & Ubiquitin-like modifier activating enzyme 7 & 301000 & $1.03 \mathrm{Up}$ \\
\hline Vwa5b1 & Von Willebrand factor A domain containing 5B1 & 313653 & $1.03 \mathrm{Up}$ \\
\hline Olr104 & Olfactory receptor 104 & 293243 & $1.02 \mathrm{Up}$ \\
\hline LOC689064 & $\beta$-globin & 689064 & -1 Down \\
\hline Fras1 & Fraser syndrome 1 & 289486 & -1.01 Down \\
\hline Zfp597 & Zinc finger protein 597 & 266774 & -1.06 Down \\
\hline LOC681849 & Similar to protein C6orf142 homolog & 681849 & -1.09 Down \\
\hline Alas2 & Aminolevulinate, delta-, synthase 2 & 25748 & -1.13 Down \\
\hline LOC500300 & Similar to hypothetical protein MGC6835 & 500300 & -1.2 Down \\
\hline Hspa1b & Heat shock $70 \mathrm{kD}$ protein $1 \mathrm{~B}$ (mapped) & 294254 & -1.21 Down \\
\hline Ccdc77 & Coiled-coil domain containing 77 & 312677 & -1.3 Down \\
\hline Oasle & 2'-5' oligoadenylate synthetase $1 \mathrm{E}$ & 494201 & -1.4 Down \\
\hline Pmp2 & Peripheral myelin protein 2 & 688790 & -1.47 Down \\
\hline Fkbp6 & FK506 binding protein 6 & 288597 & -1.98 Down \\
\hline $\operatorname{Prx}$ & Periaxin & 78960 & -2.16 Down \\
\hline $\mathrm{Mpz}$ & Myelin protein zero & 24564 & -2.92 Down \\
\hline
\end{tabular}

B, Exclusively expressed genes in MOMa group

\begin{tabular}{llcc}
\hline Gene symbol & \multicolumn{1}{c}{ Description } & Gene ID & Fold-change \\
\hline Myoc & Myocilin & 81523 & 2.47 Up \\
Samsn1 & SAM domain, SH3 domain and nuclear & 170637 & 1.48 Up \\
& localization signals, 1 & 298975 & 1.45 Up \\
Scin & Scinderin & 58982 & 1.35 Up \\
Ncan & Neurocan & 25123 & 1.34 Up \\
Tagln & Transgelin & 83518 & 1.31 Up \\
Aplnr & Apelin receptor & 298784 & 1.28 Up \\
Nlrc4 & NLR family, CARD domain containing 4 & 306792 & 1.27 Up \\
S1pr3 & Sphingosine-1-phosphate receptor 3 & 313770 & 1.26 Up \\
Mxra8 & Matrix-remodelling associated 8 & 296090 & 1.24 Up
\end{tabular}


Table IV. Continued.

B, Exclusively expressed genes in MOMa group

\begin{tabular}{|c|c|c|c|}
\hline Gene symbol & Description & Gene ID & Fold-change \\
\hline Plin2 & Perilipin 2 & 298199 & $1.23 \mathrm{Up}$ \\
\hline Epyc & Epiphycan & 314772 & $1.23 \mathrm{Up}$ \\
\hline Chdh & Choline dehydrogenase & 290551 & $1.22 \mathrm{Up}$ \\
\hline Hlx & H2.0-like homeobox & 364069 & $1.19 \mathrm{Up}$ \\
\hline Cenpf & Centromere protein $\mathrm{F}$ & 257649 & $1.19 \mathrm{Up}$ \\
\hline Aoah & Acyloxyacyl hydrolase (neutrophil) & 498757 & $1.17 \mathrm{Up}$ \\
\hline Spta1 & Spectrin, $\alpha$, erythrocytic 1 (elliptocytosis 2 ) & 289257 & $1.15 \mathrm{Up}$ \\
\hline Trim47 & Tripartite motif-containing 47 & 690374 & $1.14 \mathrm{Up}$ \\
\hline Abi3 & ABI family, member 3 & 303476 & $1.13 \mathrm{Up}$ \\
\hline Ssc $5 d$ & $\begin{array}{l}\text { Scavenger receptor cysteine rich } \\
\text { domain containing ( } 5 \text { domains) }\end{array}$ & 308341 & $1.13 \mathrm{Up}$ \\
\hline Epm2aip1 & EPM2A (laforin) interacting protein 1 & 316021 & -1.02 Down \\
\hline LOC691921 & Hypothetical protein LOC691921 & 691921 & -1.04 Down \\
\hline Klhl11 & Kelch-like 11 (Drosophila) & 287706 & -1.09 Down \\
\hline Ppargclb & $\begin{array}{l}\text { Peroxisome proliferator-activated receptor } \gamma \text {, } \\
\text { coactivator } 1 \beta\end{array}$ & 291567 & -1.11 Down \\
\hline Pcdhb6 & Protocadherin $\beta 6$ & 291653 & -1.14 Down \\
\hline Tox 2 & TOX high mobility group box family member 2 & 311615 & -1.22 Down \\
\hline Map9 & Microtubule-associated protein 9 & 310544 & -1.26 Down \\
\hline RGD1309108 & Similar to hypothetical protein FLJ23554 & 315578 & -1.55 Down \\
\hline
\end{tabular}

C, Exclusively expressed genes in Ma group

\begin{tabular}{|c|c|c|c|}
\hline Gene symbol & Description & Gene ID & Fold-change \\
\hline Defb3 & $\beta$-defensin 3 & 641623 & $3.52 \mathrm{Up}$ \\
\hline RT1-Da & RT1 class II, locus Da & 294269 & $2.60 \mathrm{Up}$ \\
\hline RT1-Ba & RT1 class II, locus Ba & 309621 & $2.59 \mathrm{Up}$ \\
\hline Pxmp4 & Peroxisomal membrane protein 4 & 282634 & $2.46 \mathrm{Up}$ \\
\hline $\mathrm{RT} 1-\mathrm{Bb}$ & RT1 class II, locus Bb & 309622 & $2.21 \mathrm{Up}$ \\
\hline Ccl11 & Chemokine (C-C motif) ligand 11 & 29397 & $2.08 \mathrm{Up}$ \\
\hline Tmem 252 & Transmembrane protein 252 & 361744 & $2.07 \mathrm{Up}$ \\
\hline Aurkb & Aurora kinase B & 114592 & $1.99 \mathrm{Up}$ \\
\hline $\mathrm{Cd} 74$ & $\begin{array}{l}\text { Cd74 molecule, major histocompatibility } \\
\text { complex, class II invariant chain }\end{array}$ & 25599 & $1.89 \mathrm{Up}$ \\
\hline Birc5 & Baculoviral IAP repeat-containing 5 & 64041 & $1.81 \mathrm{Up}$ \\
\hline Lmcd1 & LIM and cysteine-rich domains 1 & 494021 & $1.80 \mathrm{Up}$ \\
\hline Fam111a & $\begin{array}{l}\text { Family with sequence similarity } 111 \text {, } \\
\text { member A }\end{array}$ & 499322 & $1.79 \mathrm{Up}$ \\
\hline RSA-14-44 & RSA-14-44 protein & 297173 & $1.77 \mathrm{Up}$ \\
\hline Kif11 & Kinesin family member 11 & 171304 & $1.70 \mathrm{Up}$ \\
\hline Vdac1 & Voltage-dependent anion channel 1 & 83529 & $1.70 \mathrm{Up}$ \\
\hline Hmgn3 & $\begin{array}{l}\text { High mobility group nucleosomal } \\
\text { binding domain } 3\end{array}$ & 113990 & $1.69 \mathrm{Up}$ \\
\hline Nalcn & Sodium leak channel, non-selective & 266760 & $1.69 \mathrm{Up}$ \\
\hline Tnfrsf14 & $\begin{array}{l}\text { Tumor necrosis factor receptor superfamily, } \\
\text { member } 14\end{array}$ & 366518 & $1.67 \mathrm{Up}$ \\
\hline Pex11a & Peroxisomal biogenesis factor $11 \alpha$ & 85249 & $1.61 \mathrm{Up}$ \\
\hline RGD1564664 & Similar to LOC387763 protein & 499839 & $1.61 \mathrm{Up}$ \\
\hline LOC100911604 & CD99 antigen-like protein 2-like, similar to & 500410 & -1.14 Down \\
\hline
\end{tabular}


Table IV. Continued.

C, Exclusively expressed genes in Ma group

\begin{tabular}{|c|c|c|c|}
\hline Gene symbol & Description & Gene ID & Fold-change \\
\hline Serpinblb & $\begin{array}{l}\text { Serine (or cysteine) peptidase inhibitor, clade B } \\
\text { member } 1 \mathrm{~b} \text {, leukocyte elastase inhibitor A-like }\end{array}$ & 306891 & -1.15 Down \\
\hline Mgll & Monoglyceride lipase & 29254 & -1.15 Down \\
\hline Lrtomt & $\begin{array}{l}\text { Leucine rich transmembrane and } \\
0 \text {-methyltransferase domain containing }\end{array}$ & 308868 & -1.16 Down \\
\hline Tas2r145 & Taste receptor, type 2, member 145 & 100363053 & -1.18 Down \\
\hline Kcnip3 & $\mathrm{Kv}$ channel interacting protein 3 , calsenilin & 65199 & -1.19 Down \\
\hline Fbll1 & Fibrillarin-like 1 & 363563 & -1.19 Down \\
\hline LOC100910054 & NF-k-B-repressing factor-like & 100910054 & -1.20 Down \\
\hline Ttll1 & Tubulin tyrosine ligase-like family, member 1 & 362969 & -1.21 Down \\
\hline Negrl & Neuronal growth regulator 1 & 59318 & -1.22 Down \\
\hline Ttll11 & Tubulin tyrosine ligase-like family, member 11 & 689746 & -1.24 Down \\
\hline Mgam & Maltase-glucoamylase & 312272 & -1.25 Down \\
\hline Apba1 & $\begin{array}{l}\text { Amyloid } \beta(\mathrm{A} 4) \text { precursor protein-binding, } \\
\text { family } \mathrm{A} \text {, member } 1\end{array}$ & 83589 & -1.26 Down \\
\hline Hoxb5 & Homeo box B5 & 497987 & -1.26 Down \\
\hline Zfp238 & Zinc finger protein 238 & 64619 & -1.27 Down \\
\hline Ddx6 & DEAD (Asp-Glu-Ala-Asp) box helicase 6 & 500988 & -1.29 Down \\
\hline LOC310902 & $\begin{array}{l}\text { Similar to Alcohol dehydrogenase 1A } \\
\text { (alcohol dehydrogenase asubunit) }\end{array}$ & 310902 & -1.30 Down \\
\hline Fgf13 & Fibroblast growth factor 13 & 84488 & -1.32 Down \\
\hline Tnnc2 & Troponin C type 2 (fast) & 296369 & -1.33 Down \\
\hline Pdyn & Prodynorphin & 29190 & -1.43 Down \\
\hline
\end{tabular}

$\log 2$ (Ratio) Mo, morphine (morphine infusion/vehicle injection/morphine challenge); Up, upregulated; Down, downregulated.

fold change in upregulation; and myocilin has been reported to mediate myelination in the peripheral nervous system (26). Furthermore, microtubule-associated protein 9 expression was decreased in the MOMa group, and this gene has been reported to serve a role in mitotic spindle formation and mitosis progression (27), implying the potential involvement of melatonin.

Reversed gene expression panel between $\mathrm{MO} / \mathrm{C}$ and $\mathrm{MOM} / \mathrm{C}$ groups. In order to clarify which genes were altered by melatonin treatment in morphine-tolerant rats, genes from the microarray data with inverted gene expression profiles between $\mathrm{MO} / \mathrm{C}$ and $\mathrm{MOMa} / \mathrm{C}$ groups were selected. Hierarchical clustering analysis was performed to construct a reversed gene expression heatmap between the $\mathrm{MO} / \mathrm{C}$ and $\mathrm{MOMa} / \mathrm{C}$ groups (Fig. 3). Genes were selected from the microarray data with the criteria of $\log _{2}$ ratio $\geq 1$ or $\leq-1$ and $\mathrm{P}<0.05$, and the expression of the genes was reversed between the $\mathrm{MO} / \mathrm{C}$ and $\mathrm{MOMa} / \mathrm{C}$ groups. The constructed panel according to the heatmap of the reversed genes was listed in Table V. The panel with inverted gene expression may be used to investigate potential pathways derived by melatonin treatment.

PANTHER pathway mapping and RT-qPCR analysis. The genes listed in Table V-A and -B were used for enrichment analysis by the PANTHER algorithm provided by the GO Consortium. The PANTHER pathway mapped 4 out of 29 genes for the genes listed in Table V-A and 10 out of 66 genes for the genes listed in Table V-B. The PANTHER-mapped pathways and associated genes are listed in Table VI-A and -B. Guanine nucleotide binding protein $\beta$ polypeptide 1 (Gnb1) was identified to participate in numerous cellular functions, including neuron-associated functions, including glutamatergic, cholinergic, GABAergic, dopaminergic, serotonergic and sympathetic neuron functions. Furthermore, Gnb1 has also been reported to participate in other pathways, including histamine $\mathrm{H} 1$ and $\mathrm{H} 2$ receptors and several hormone receptor signals. Gnb1 was upregulated 1.4-fold in the MO group and downregulated 1.3-fold in the MOMA group; this result implies the potential of a melatonin-mediated pathway via the repression of $G_{\beta}$ expression and signaling. On the other hand, the genes mapped in Table VI-B mainly participated in cell proliferation and migration in addition to cytoskeleton reconstruction. For example, a gene named inositol 1,4,5-trisphosphate receptor, type 3 (Itpr3) was downregulated 1.7-fold in the MO group but was upregulated 1.8-fold in the MOMA group. A number of pathways associated with Itpr3, including inflammatory, cell proliferation and migration, $G$ protein mediated and vaso-relaxation pathways, were suggested. The genes mentioned in Table VI-A and VI-B were selected and their 


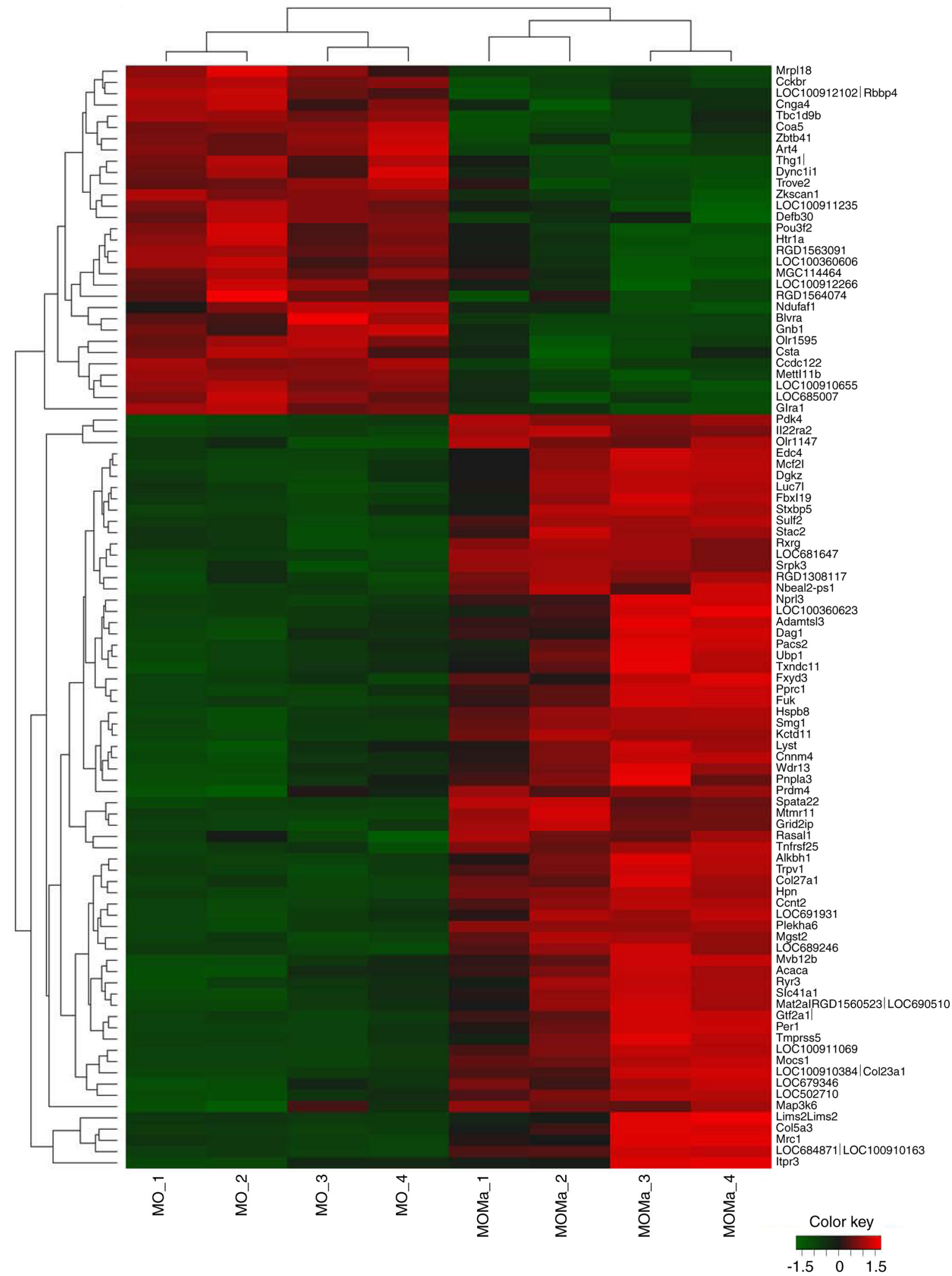

Figure 3. Hierarchical clustering analysis of genes with expression completely inverted between the MO and MOMa group. Upregulated genes are indicated in red, and downregulated genes are presented in green. The signal intensity values of each sample were transformed to $\log _{2}$ values and subjected to hierarchical clustering using standard correlation. MO, morphine (morphine infusion/vehicle injection/morphine challenge); MOMa, (morphine infusion/melatonin injection/morphine challenge). 
Table V. Genes with inverted expressions between Mo and MOMa group

A, Genes with upregulated expression in the MO group but downregulated expression in the MOMa group

\begin{tabular}{|c|c|c|c|c|}
\hline Gene symbol & Description & Gene ID & $\begin{array}{l}\text { Fold } \\
\text { MO }\end{array}$ & $\begin{array}{c}\text { Fold } \\
\text { MOMA }\end{array}$ \\
\hline Glra1 & Glycine receptor, $\alpha 1$ & 25674 & 2.10 & 0.65 \\
\hline Olr1595 & Olfactory receptor 1595 & 304990 & 1.70 & 0.66 \\
\hline Ndufaf1 & NADH dehydrogenase (ubiquinone) complex I, assembly factor 1 & 296086 & 1.42 & 0.72 \\
\hline RGD1563091 & Similar to OEF2 & 500011 & 1.40 & 0.79 \\
\hline Gnb1 & Guanine nucleotide binding protein (G protein), $\beta$ polypeptide 1 & 24400 & 1.40 & 0.76 \\
\hline Ccdc122 & Coiled-coil domain containing 122 & 100360752 & 1.39 & 0.61 \\
\hline Csta & Cystatin A (stefin A) & 288067 & 1.35 & 0.70 \\
\hline Blvra & Biliverdin reductase $\mathrm{A}$ & 116599 & 1.33 & 0.70 \\
\hline MGC114464 & Similar to expressed sequence AI836003 & 500925 & 1.32 & 0.75 \\
\hline LOC 100910655 & Paralemmin-2-like & 100910655 & 1.31 & 0.64 \\
\hline Dync1i1 & Dynein cytoplasmic 1 intermediate chain 1 & 29564 & 1.31 & 0.79 \\
\hline LOC685007 & Similar to unc-93 homolog A & 685007 & 1.30 & 0.68 \\
\hline Cckbr & Cholecystokinin B receptor & 25706 & 1.29 & 0.78 \\
\hline Art4 & ADP-ribosyltransferase 4 & 312806 & 1.29 & 0.72 \\
\hline Zbtb41 & Cytochrome $\mathrm{C}$ oxidase assembly factor 5 & 503252 & 1.28 & 0.75 \\
\hline Cnga4 & Cyclic nucleotide gated channel $\alpha 4$ & 85258 & 1.28 & 0.78 \\
\hline Thg11 & tRNA-histidine guanylyltransferase 1 -like (S. cerevisiae) & 303067 & 1.26 & 0.82 \\
\hline Mettl11b & Methyltransferase like 11B & 289167 & 1.25 & 0.68 \\
\hline LOC 100911235 & Mediator of RNA polymerase II transcription subunit 7-like & 100911235 & 1.25 & 0.81 \\
\hline Htrla & 5-hydroxytryptamine (serotonin) receptor $1 \mathrm{~A}, \mathrm{G}$ protein-coupled & 24473 & 1.24 & 0.75 \\
\hline Pou3f2 & POU class 3 homeobox 2 & 29588 & 1.24 & 0.77 \\
\hline
\end{tabular}

$\mathrm{B}$, Genes with downregulated expression in the MO group but upregulated expression in the MOMa group

\begin{tabular}{|c|c|c|c|c|}
\hline Gene symbol & Description & Gene ID & $\begin{array}{l}\text { Fold } \\
\mathrm{MO}\end{array}$ & $\begin{array}{c}\text { Fold } \\
\text { MOMA }\end{array}$ \\
\hline Itpr3 & Inositol 1,4,5-trisphosphate receptor, type 3 & 25679 & 0.59 & 1.82 \\
\hline Mocs1 & Molybdenum cofactor synthesis 1 & 301221 & 0.69 & 1.66 \\
\hline Col5a3 & Collagen, type $\mathrm{V}, \alpha 3$ & 60379 & 0.73 & 1.66 \\
\hline Mrc1 & Mannose receptor, $\mathrm{C}$ type 1 & 291327 & 0.66 & 1.65 \\
\hline Lims2 & LIM and senescent cell antigen like domains 2 & 361303 & 0.65 & 1.63 \\
\hline Gtf2a11 & General transcription factor IIA, 1-like & 316711 & 0.76 & 1.58 \\
\hline Olr1147 & Olfactory receptor 1147 & 300408 & 0.60 & 1.55 \\
\hline Ccnt2 & Cyclin T2 & 304758 & 0.82 & 1.51 \\
\hline Map3k6 & Mitogen-activated protein kinase kinase kinase 6 & 313022 & 0.64 & 1.45 \\
\hline Tnfrsf 25 & Tumor necrosis factor receptor superfamily, member 25 & 500592 & 0.71 & 1.43 \\
\hline Slc41a1 & Solute carrier family 41 , member 1 & 363985 & 0.83 & 1.43 \\
\hline Mvb12b & Multivesicular body subunit 12B & 362118 & 0.80 & 1.42 \\
\hline Acaca & Acetyl-CoA carboxylase $\alpha$ & 60581 & 0.77 & 1.38 \\
\hline Ryr3 & Ryanodine receptor 3 & 170546 & 0.77 & 1.38 \\
\hline Col27a1 & Collagen, type XXVII, $\alpha 1$ & 298101 & 0.83 & 1.36 \\
\hline Rasal1 & RAS protein activator like 1 (GAP1 like) & 360814 & 0.72 & 1.36 \\
\hline Rasal1 & RAS protein activator like 1 (GAP1 like) & 360814 & 0.72 & 1.36 \\
\hline Mat2a & Methionine adenosyltransferase II & 690510 & 0.79 & 1.29 \\
\hline er1 & Period circadian clock 1 & 287422 & 0.63 & 1.25 \\
\hline Dgkz & Diacylglycerol kinase $\zeta$ & 81821 & 0.77 & 1.24 \\
\hline
\end{tabular}

Mo, morphine (morphine infusion/vehicle injection/morphine challenge); MOMa, (morphine infusion/melatonin injection/morphine challenge). 
Table VI. PANTHER pathway mapped cellular functions of four selected genes from Table V-A and -B.

A, PANTHER pathway mapped cellular functions of four selected genes from Table V-A

\begin{tabular}{|c|c|c|}
\hline Gene name & Cellular functions & Pathways \\
\hline \multirow{25}{*}{$\begin{array}{l}\text { Guanine nucleotide binding protein, } \\
\beta \text { polypeptide } 1(\mathrm{Gnb} 1)\end{array}$} & \multicolumn{2}{|l|}{ Neuron } \\
\hline & Pain_Relief_anagelsia & Opioid proopiomelanocortin pathway \\
\hline & Pain_Relief_anagelsia & Opioid proenkephalin pathway \\
\hline & Pain_Relief_anagelsia & Enkephalin release \\
\hline & Pain_Relief_anagelsia & $\begin{array}{l}\text { Cortocotropin releasing factor receptor signaling } \\
\text { pathway }\end{array}$ \\
\hline & Pain_Relief_anagelsia & Opioid prodynorphin pathway \\
\hline & Glutamertergic & $\begin{array}{l}\text { Metabotropic glutamate receptor group II } \\
\text { pathway }\end{array}$ \\
\hline & Glutamertergic & $\begin{array}{l}\text { Heterotrimeric G-protein signaling pathway-rod } \\
\text { outer segment phototransduction }\end{array}$ \\
\hline & Glutamertergic & $\begin{array}{l}\text { Metabotropic glutamate receptor group III } \\
\text { pathway }\end{array}$ \\
\hline & Cholinergic & $\begin{array}{l}\text { Muscarinic acetylcholine receptor } 1 \text { and } 3 \\
\text { signaling pathway }\end{array}$ \\
\hline & Cholinergic & $\beta 1$ adrenergic receptor signaling pathway \\
\hline & Cholinergic & $\begin{array}{l}\text { Muscarinic acetylcholine receptor } 2 \text { and } 4 \\
\text { signaling pathway }\end{array}$ \\
\hline & GABAergic & GABA-B_receptor_II_signaling \\
\hline & GABAergic & Endogenous_cannabinoid_signaling \\
\hline & Dopaminergic & Dopamine receptor mediated signaling pathway \\
\hline & Serotonergic & 5HT2 type receptor mediated signaling pathway \\
\hline & Serotonergic & 5HT4 type receptor mediated signaling pathway \\
\hline & Depolarization & Nicotine pharmacodynamics pathway \\
\hline & Sympathetic & $\beta 3$ adrenergic receptor signaling pathway \\
\hline & $\mathrm{G}$ protein mediated pathway & $\beta 2$ adrenergic receptor signaling pathway \\
\hline & \multicolumn{2}{|l|}{ Inflammation } \\
\hline & G protein mediated pathway & $\begin{array}{l}\text { Histamine } \mathrm{H} 1 \text { receptor mediated signaling } \\
\text { pathway }\end{array}$ \\
\hline & $\mathrm{G}$ protein mediated pathway & Histamine $\mathrm{H} 2$ receptor mediated signaling pathway \\
\hline & $\mathrm{G}$ protein mediated pathway & $\begin{array}{l}\text { Heterotrimeric G-protein signaling pathway-Gq a } \\
\text { and Go } \alpha \text { mediated pathway }\end{array}$ \\
\hline & G protein mediated pathway & $\begin{array}{l}\text { Thyrotropin-releasing hormone receptor } \\
\text { signaling pathway }\end{array}$ \\
\hline
\end{tabular}

Others

Signaling pathway

Signaling pathway

Signaling pathway

Angiogenesis

Muscle contraction

Cell migration

Cholecystokinin B receptor (Cckbr)

Cell migration

5-hydroxytryptamine (serotonin)

Neuron_Serotonergic

receptor $1 \mathrm{~A}$

G protein-coupled (Htr1a)

G protein mediated pathway

Dynein cytoplasmic 1 intermediate

Neuron

Gonadotropin releasing hormone receptor pathway

PI3 kinase pathway

Wnt signaling pathway

Angiotensin II-stimulated signaling through

$\mathrm{G}$ proteins and $\beta$-arrestin

Oxytocin receptor mediated signaling pathway

CCKR signaling pathway

CCKR signaling pathway

5HT1 type receptor mediated signaling pathway

Heterotrimeric G-protein signaling pathway-Gi $\alpha$ and Gs $\alpha$ mediated pathway

Huntington disease 
Table VI. Continued.

B, PANTHER pathway mapped cellular functions of four selected genes from Table V-B

\begin{tabular}{|c|c|c|}
\hline Gene name & Cellular functions & Pathways \\
\hline \multirow[t]{9}{*}{$\begin{array}{l}\text { Inositol 1,4,5-trisphosphate } \\
\text { receptor type } 3 \text { (Itpr3) }\end{array}$} & Inflammation and immunity & $\begin{array}{l}\text { Inflammation mediated by chemokine } \\
\text { and cytokine signaling pathway }\end{array}$ \\
\hline & & $\begin{array}{l}\text { Histamine } \mathrm{H} 1 \text { receptor mediated signaling } \\
\text { pathwayB cell activation }\end{array}$ \\
\hline & Cell proliferation and migration & $\begin{array}{l}\text { Gonadotropin releasing hormone receptor pathway } \\
\text { Wnt signaling pathway }\end{array}$ \\
\hline & & $\begin{array}{l}\text { Muscarinic acetylcholine receptor } 1 \text { and } 3 \\
\text { signaling pathway }\end{array}$ \\
\hline & & PDGF signaling pathway \\
\hline & G protein mediated pathway & Angiotensin II-stimulated signaling through \\
\hline & & $\mathrm{G}$ proteins and $\beta$-arrestin \\
\hline & & $\begin{array}{l}\text { Heterotrimeric G-protein signaling pathway-Gq } \alpha \\
\text { and Go } \alpha \text { mediated pathway }\end{array}$ \\
\hline & Vaso relaxation & Endothelin signaling pathway \\
\hline \multirow{3}{*}{$\begin{array}{l}\text { RAS protein activator like } 1 \\
\text { (Rasal1) }\end{array}$} & Cell proliferation and migration & FGF signaling pathway \\
\hline & & EGF receptor signaling pathway \\
\hline & & PDGF signaling pathway \\
\hline \multirow{2}{*}{$\begin{array}{l}\text { General transcription factor } \\
\text { subunit 1-like (Gtf2a1l) }\end{array}$} & Transcription regulation & Transcription regulation by bZIP transcription $2 \mathrm{~A}$ \\
\hline & & General transcription regulation \\
\hline \multirow{2}{*}{$\begin{array}{l}\text { Period circadian protein } \\
\text { homolog } 1 \text { (Per1) }\end{array}$} & Biochemical oscillator & Circadian clock system \\
\hline & Cell proliferation and migration & Gonadotropin releasing hormone receptor pathway \\
\hline S-adenosylmethionine & Enzyme activity & $\mathrm{S}$ adenosyl methionine biosynthesis \\
\hline
\end{tabular}

synthase isoform type-2

(Mat2a)

Diacylglycerol kinase $\zeta$ (Dgkz)

$\alpha 4$ type $\mathrm{V}$ collagen (Col5a3)

Cell proliferation and migration

Gonadotropin releasing hormone receptor pathway

Collagen $\alpha-1$ (XXVII)

chain (Col27a1)

LIM and senescent cell

antigen-like-containing

domain protein (Lims2)

Mitogen-activated protein

kinase kinase kinase 6

Cytoskeleton

Cytoskeleton

Cytoskeleton

Cell proliferation and migration
Integrin signaling pathway

Integrin signaling pathway

Integrin signaling pathway

FGF signaling pathway

(Map3k6)

gene expressions were verified using RT-qPCR (Fig. 4). All the genes selected here demonstrated an accordance with the expression trends of the microarray results. The results indicate the potential signaling pathways of melatonin in the rat spinal cord for the restoration of cell proliferation and migration through cytoskeleton reconstruction.

\section{Discussion}

By using microarray analysis of rat spinal cords from different treatment groups, the gene expression alterations in different conditions were identified. Panels of gene expression with upregulation in the MO group but downregulation in the MOMa group and also inverted gene expression profiles between the $\mathrm{MO} / \mathrm{C}$ and $\mathrm{MOMa} / \mathrm{C}$ groups were constructed. Among them, a number of notable genes were identified following PANTHER pathway mapping. For example, Gnb1 is one of the three subunits of heterotrimeric guanine nucleotide binding proteins ( $\mathrm{G}$ proteins), which integrate signals between G protein coupled receptors (GPCR) (28). GPCR signaling is initiated when a ligand-bound receptor activates heterotrimeric $G$ proteins on the inner leaflet of the plasma membrane by catalyzing the exchange of GDP for GTP on G protein $\alpha$ subunit $(G \alpha)$, causing it to release the $G \beta \gamma$ subunits. The 

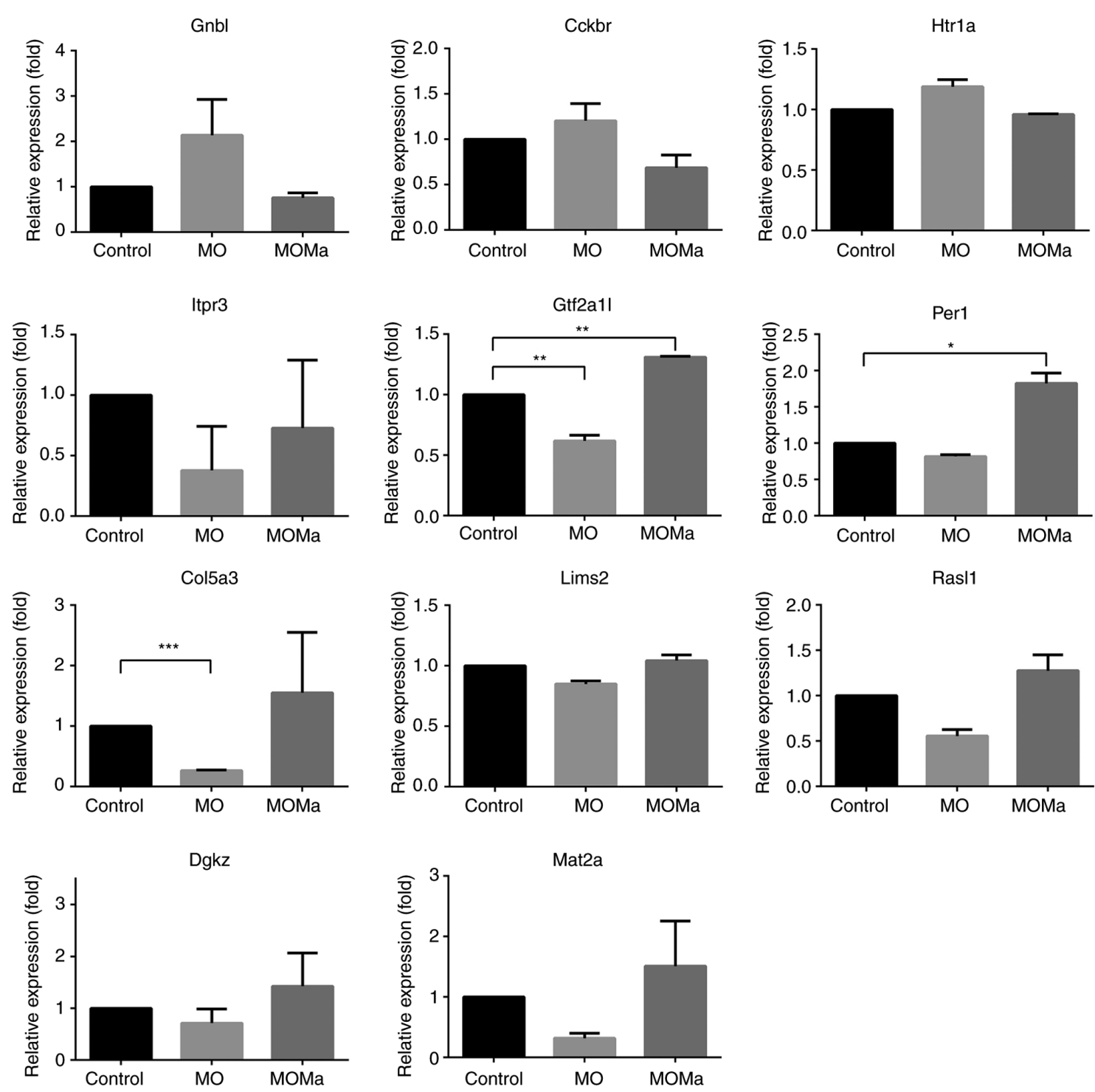

Figure 4. Expressions of genes of interests determined by reverse transcription-quantitative polymerase chain reaction. All expression levels were normalized using GAPDH expression. ${ }^{*} \mathrm{P}<0.05,{ }^{* *} \mathrm{P}<0.01$ and ${ }^{* * *} \mathrm{P}<0.001$ with comparison shown by lines. MO, morphine (morphine infusion/vehicle injection/morphine challenge); MOMa, (morphine infusion/melatonin injection/morphine challenge); Gnb1, guanine nucleotide binding protein $\beta$ polypeptide 1; Cckbr, cholecystokinin B receptor; Htrla, 5-hydroxytryptamine receptor 1A; Itpr3, inositol 1,4,5-trisphosphate receptor type 3; Gtf2a1, general transcription factor IIA subunit 1; Perl, period circadian regulator 1; Col5a3, collagen type $\mathrm{V} \alpha 3$ chain; Lims2, LIM zinc finger domain containing 2; RasI1, RAS protein activator like 1, Dgkz, diaglycerol kinase $\zeta$; Mat2a, methionine adenosyltransferase 2A.

GTP-bound $\mathrm{G} \alpha$ and free $\mathrm{G} \beta \gamma$ subunits transmit the signal by engaging intracellular effector molecules until GTP is hydrolysed and the $\beta$ subunits are recoupled to the $\alpha$ subunit to terminate signal transduction receptors and effectors (29). According to a study by Klein et al (30), Gnb1 belongs to a group of genes that is night/day differentially expressed in the pineal body; this result implies the potential involvement of Gnb1 in melatonin treatment. Furthermore, $\beta$-arrestin- 2 mediated desensitization of the $\mu$-opioid receptor is involved in morphine tolerance $(31,32)$. In the present data, Gnb1 was upregulated in the MO group but downregulated by melatonin treatment; this result indicates the potential of a role of melatonin in the activation and desensitization of GPCR.

Another gene, Itpr3, was downregulated in the MO group but upregulated in the MOMA group. It was also produced following PANTHER pathway mapping. Itpr3 is the receptor for inositol 1,4,5-trisphosphate $\left(\mathrm{IP}_{3}\right)$, which mediates the release of intracellular calcium (33). Following $\mathrm{IP}_{3}$ binding, Itpr3 permits calcium flow out of the endoplasmic reticulum (34) and results in the activation of transient receptor potential cation channel subfamily $\mathrm{M}$ member 5 , which results in membrane depolarization (35). In the case of melatonin treatment with Itpr3 upregulation, it was speculated that depolarization in certain nerve cells in the spinal cord may participate in the melatonin-derived attenuation of antinociceptive morphine tolerance.

In the present model, long-term morphine administration did not affect opioid receptor expression potentially due to the alteration of signal transduction and receptor- $G$ protein coupling. It has been demonstrated that the downregulation of opioid receptors following chronic agonist exposure induces tolerance $(36,37)$. However, a controversial report did not observe the downregulation of opioid receptors in tolerant animals (38). On the other hand, studies suggest that 
$\beta$-arrestin-2 (Arrb2) binding causes OPR desensitization, and OPR endocytosis and recycling are required for receptor resensitization. This result suggests the potential involvement of Arrb2 with morphine tolerance (31). However, in the present data, the expression of Arrb2 between the groups was similar; the results did not support the potential involvement of Arrb2 with morphine tolerance. Combining the previous discussion with the present data, it was postulated that the expression changes of opioid receptor and Arrb2 are not mandatory for morphine tolerance mechanisms.

There are limitations in descriptive microarray studies. The first limitation is that sequences in the microarray will be refined in newer databases and will result in different outcomes. Secondly, the associations between mRNAs may be different between mice and humans (39). The third limitation is that the gene expression detected by microarrays is descriptive and may not reflect protein expression and subsequent post-transcriptional modifications (40). However, identifying changes in gene expression in tissues with a high-throughput approach remains a good option as it can be performed in one experiment. Even though the present study uses descriptive microarray analysis, a panel of genes that are specifically expressed in morphine-tolerant animals with or without melatonin treatment was produced. As it is impossible to collect the spinal cord from patients, therefore future studies will use drug databases to identify drugs which target the genes of interest in the present study and use the drugs in the same rat models as in the present study to assess the dosage and efficacy of the drug in the treatment of relieving the morphine tolerance. Following that, the drugs with efficacy in the rat model will be used in humans. Next, patients who are under chronic treatment and with morphine tolerance may be recruited to assess the efficacy of the drug in order to ascertain the results of the present and provide novel treatment methods. From the present microarray analysis, novel insight into the molecular profiles associated with morphine tolerance and the effects of melatonin was provided. The present study offers a foundation for future specific hypotheses testing on potential therapeutic targets derived from melatonin treatment in patients with long-term morphine exposure.

\section{Acknowledgements}

The authors would like to thank Dr. Chih-Cheng Chien for his advice about the research.

\section{Funding}

The present study was supported by research grants from Ministry of Science and Technology (grant no. 105-231 4-B-281-003-MY2) and Cathay General Hospital (grant no. CGH-MR-A10518) in Taiwan.

\section{Authors' contributions}

YCC and RYT wrote the manuscript, were responsible for conception and design, data analysis and interpretation. YTS performed the microarray data analysis and interpretation. IJC was in charge of the animal experiments. TYT and YYM performed the RT-qPCR analysis and interpretation. CSW was responsible for conception and design, financial support, administrative support, final approval of manuscript.

\section{Ethics approval and consent to participate}

The use of rats in this study adhered to the Guiding Principles in the Care and Use of Animals of the American Physiology Society and was ethically approved by the National Defense Medical Center Animal Care and Use Committee (Taipei, Taiwan).

\section{Patient consent for publication}

Not applicable.

\section{Availability of data and materials}

The datasets used and/or analyzed during the current study are available from the corresponding author on reasonable request.

\section{Competing interests}

The authors declare that they have no competing interests.

\section{References}

1. Chen WW, Zhang $X$ and Huang WJ: Pain control by melatonin: Physiological and pharmacological effects. Exp Ther Med 12: 1963-1968, 2016.

2. Pasternak GW: When it comes to opiates, just say NO. J Clin Invest 117: 3185-3187, 2007.

3. Günther T, Dasgupta P, Mann A, Miess E, Kliewer A, Fritzwanker S, Steinborn R and Schulz S: Targeting multiple opioid receptors-improved analgesics with reduced side effects? Br J Pharmacol 175: 2857-2868, 2018.

4. Martini L and Whistler JL: The role of mu opioid receptor desensitization and endocytosis in morphine tolerance and dependence. Curr Opin Neurobiol 17: 556-564, 2007.

5. Rosenblum A, Marsch LA, Joseph H and Portenoy RK: Opioids and the treatment of chronic pain: Controversies, current status, and future directions. Exp Clin Psychopharmacol 16: 405-416, 2008.

6. Pang CS, Tsang SF and Yang JC: Effects of melatonin, morphine and diazepam on formalin-induced nociception in mice. Life Sci 68: 943-951, 2001.

7. Lin SH, Huang YN, Kao JH, Tien LT, Tsai RY and Wong CS: Melatonin reverses morphine tolerance by inhibiting microglia activation and HSP27 expression. Life Sci 152: 38-43, 2016.

8. Song L, Wu C and Zuo Y: Melatonin prevents morphine-induced hyperalgesia and tolerance in rats: Role of protein kinase $\mathrm{C}$ and N-methyl-D-aspartate receptors. BMC Anesthesiol 15: 12, 2015.

9. Xin W, Chun W, Ling L and Wei W: Role of melatonin in the prevention of morphine-induced hyperalgesia and spinal glial activation in rats: Protein kinase $\mathrm{C}$ pathway involved. Int J Neurosci 122: 154-163, 2012.

10. Feng YM, Jia YF, Su LY, Wang D, Lv L, Xu L and Yao YG: Decreased mitochondrial DNA copy number in the hippocampus and peripheral blood during opiate addiction is mediated by autophagy and can be salvaged by melatonin. Autophagy 9: 1395-1406, 2013.

11. Yahyavi-Firouz-Abadi N, Tahsili-Fahadan P, Riazi K, Ghahremani MH and Dehpour AR: Melatonin enhances the anticonvulsant and proconvulsant effects of morphine in mice: Role for nitric oxide signaling pathway. Epilepsy Res 75: 138-144, 2007.

12. Raghavendra V and Kulkarni SK: Reversal of morphine tolerance and dependence by melatonin: Possible role of central and peripheral benzodiazepine receptors. Brain Res 834: 178-181, 1999.

13. Garmabi B, Vousooghi N, Vosough M, Yoonessi A, Bakhtazad A and Zarrindast MR: Effect of circadian rhythm disturbance on morphine preference and addiction in male rats: Involvement of period genes and dopamine D1 receptor. Neuroscience 322: 104-114, 2016. 
14. Fan Y, Liang X, Wang R and Song L: Role of endogenous melatoninergic system in development of hyperalgesia and tolerance induced by chronic morphine administration in rats. Brain Res Bull 135: 105-112, 2017

15. Chou KY, Tsai RY, Tsai WY, Wu CT, Yeh CC, Cherng CH and Wong CS: Ultra-low dose (+)-naloxone restores the thermal threshold of morphine tolerant rats. J Formos Med Assoc 112: 795-800, 2013.

16. Guiding principles in the care and use of animals of the American physiology society.

17. Grossman ML, Basbaum AI and Fields HL: Afferent and efferent connections of the rat tail flick reflex (a model used to analyze pain control mechanisms). J Comp Neurol 206: 9-16, 1982.

18. Tsai RY, Chou KY, Shen CH, Chien CC, Tsai WY, Huang YN, Tao PL, Lin YS and Wong CS: Resveratrol regulates N-methyl-Daspartate receptor expression and suppresses neuroinflammation in morphine-tolerant rats. Anesth Analg 115: 944-952, 2012.

19. Pirooznia M, Nagarajan V and Deng Y: GeneVenn-A web application for comparing gene lists using Venn diagrams. Bioinformation 1: 420-422, 2007.

20. Xu J, Kelly R, Fang H and Tong W: ArrayTrack: A free FDA bioinformatics tool to support emerging biomedical research-an update. Hum Genomics 4: 428-434, 2010.

21. Saldanha AJ: Java Treeview-extensible visualization of microarray data. Bioinformatics 20: 3246-3248, 2004.

22. Gene ontology Enrichment analysis website.

23. Mi H, Muruganujan A and Thomas PD: PANTHER in 2013 : Modeling the evolution of gene function, and other gene attributes, in the context of phylogenetic trees. Nucleic Acids Res 41 (Database Issue): D377-D386, 2013.

24. Livak KJ and Schmittgen TD: Analysis of relative gene expression data using real-time quantitative PCR and the 2(-Delta Delta C(T)) method. Methods 25: 402-408, 2001.

25. Roeckel LA, Le Coz GM, Gavériaux-Ruff C and Simonin F: Opioid-induced hyperalgesia: Cellular and molecular mechanisms. Neuroscience 338: 160-182, 2016.

26. Kwon HS, Johnson TV, Joe MK, Abu-Asab M, Zhang J, Chan CC and Tomarev SI: Myocilin mediates myelination in the peripheral nervous System through ErbB2/3 signaling. J Biol Chem 288: 26357-26371, 2013.

27. Fontenille L, Rouquier S, Lutfalla G and Giorgi D: Microtubuleassociated protein 9 (Map9/Asap) is required for the early steps of zebrafish development. Cell Cycle 13: 1101-1114, 2014

28. Downes GB and Gautam N: The G protein subunit gene families. Genomics 62: 544-552, 1999 .

29. Thal DM, Vuckovic Z, Draper-Joyce CJ, Liang YL, Glukhova A, Christopoulos A and Sexton PM: Recent advances in the determination of $\mathrm{G}$ protein-coupled receptor structures. Curr Opin Struct Biol 51: 28-34, 2018.
30. Klein DC, Bailey MJ, Carter DA, Kim JS, Shi Q, Ho AK, Chik CL, Gaildrat P, Morin F, Ganguly S, et al: Pineal function: Impact of microarray analysis. Mol Cell Endocrinol 314: 170-183, 2010.

31. Bohn LM, Gainetdinov RR, Lin FT, Lefkowitz RJ and Caron MG: $\mathrm{Mu}$-opioid receptor desensitization by beta-arrestin-2 determines morphine tolerance but not dependence. Nature 408: 720-723, 2000.

32. Zuo Z: The role of opioid receptor internalization and beta-arrestins in the development of opioid tolerance. Anesth Analg 101: 728-734, table of contents, 2005.

33. Nagaleekar VK, Diehl SA, Juncadella I, Charland C, Muthusamy N, Eaton S, Haynes L, Garrett-Sinha LA, Anguita J and Rincón M: IP3 receptor-mediated $\mathrm{Ca} 2+$ release in naive CD4 T cells dictates their cytokine program. J Immunol 181: 8315-8322, 2008

34. Taylor CW and Tovey SC: IP(3) receptors: Toward understanding their activation. Cold Spring Harb Perspect Biol 2: a004010, 2010.

35. Liu D and Liman ER: Intracellular Ca2+ and the phospholipid PIP2 regulate the taste transduction ion channel TRPM5. Proc Natl Acad Sci USA 100: 15160-15165, 2003.

36. Dang VC and Christie MJ: Mechanisms of rapid opioid receptor desensitization, resensitization and tolerance in brain neurons. $\mathrm{Br}$ J Pharmacol 165: 1704-1716, 2012.

37. Stafford K, Gomes AB, Shen J and Yoburn BC: mu-Opioid receptor downregulation contributes to opioid tolerance in vivo. Pharmacol Biochem Behav 69: 233-237, 2001.

38. Polastron J, Meunier JC and Jauzac P: Chronic morphine induces tolerance and desensitization of mu-opioid receptor but not down-regulation in rabbit. Eur J Pharmacol 266: 139-146, 1994.

39. Wang L, Liu H, Jiao Y, Wang E, Clark SH, Postlethwaite AE, $\mathrm{Gu} \mathrm{W}$ and Chen $\mathrm{H}$ : Differences between mice and humans in regulation and the molecular network of collagen, type III, alpha-1 at the gene expression level: Obstacles that translational research must overcome. Int J Mol Sci 16: 15031-15056, 2015.

40. Brodsky AN, Caldwell M and Harcum SW: Glycosylation and post-translational modification gene expression analysis by DNA microarrays for cultured mammalian cells. Methods 56: 408-417, 2012. 